\title{
Urgences
}

\section{La mort...}

\section{Danièle Grenier}

Numéro 29, octobre 1990

\section{Éclats d'œuvre}

URI : https://id.erudit.org/iderudit/025609ar

DOI : https://doi.org/10.7202/025609ar

Aller au sommaire du numéro

\section{Éditeur(s)}

Urgences

\section{ISSN}

0226-9554 (imprimé)

1927-3924 (numérique)

Découvrir la revue

\section{Citer ce document}

Grenier, D. (1990). La mort... Urgences, (29), 71-71.

https://doi.org/10.7202/025609ar d'utilisation que vous pouvez consulter en ligne.

https://apropos.erudit.org/fr/usagers/politique-dutilisation/ 


\section{Danièle Grenier}

La mort est un coup bas de la vie.

La mort est un homme à bicyclette qui, à l'aube, s'arrête sous ma fenêtre et me regarde en silence. Heureusement je suis celle qui, tirée de sa rêverie, courbe la tête vers un homme au regard noir, et s'éloigne.

La vie est une vieillarde chinoise dans le métro de Hong Kong, et qui marche les bras ballants, portant en mémoire sur son dos un lourd et invisible panier. Dorénavant, le métro de Hong Kong est une rizière. 